\title{
SearCh for humourlstic and Extravagant acroNyms and Thoroughly Inappropriate names For Important Clinical trials (SCIENTIFIC): qualitative and quantitative systematic study
}

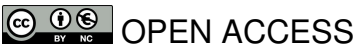

Anton Pottegård research fellow ${ }^{1}$, Maija Bruun Haastrup medical doctor ${ }^{2}$, Tore Bjerregaard Stage PhD student ${ }^{1}$, Morten Rix Hansen PhD student ${ }^{1}$, Kasper Søltoft Larsen PhD student ${ }^{1}$, Peter Martin Meegaard pharmacist ${ }^{3}$, Line Haugaard Vrdlovec Meegaard pharmacist ${ }^{4}$, Henrik Horneberg editorial manager ${ }^{1}$, Charlotte Gils medical doctor ${ }^{2}$, Dorthe Dideriksen pharmacist ${ }^{2}$, Lise Aagaard professor ${ }^{1}$, Anna Birna Almarsdottir professor ${ }^{12}$, Jesper Hallas professor ${ }^{12}$, Per Damkier consultant, assistant professor $^{12}$

${ }^{1}$ Clinical Pharmacology, Institute of Public Health, University of Southern Denmark, DK-5000 Odense C, Denmark; ${ }^{2}$ Department of Clinical Chemistry and Pharmacology, Odense University Hospital, Odense C, Denmark; ${ }^{3}$ Capital Region Pharmacy, Clinical pharmaceutical Services, Rigshospitalet, Copenhagen, Denmark; ${ }^{4}$ Capital Region Pharmacy, Clinical pharmaceutical Services, Nordsjællands Hospital, Hillerød, Denmark

\begin{abstract}
Objectives To describe the development of acronym use across five major medical specialties and to evaluate the technical and aesthetic quality of the acronyms.

Design Acronyms obtained through a literature search of Pubmed.gov followed by a standardised assessment of acronym quality (BEAUTY and CHEATING criteria).

Participants Randomised controlled trials within psychiatry, rheumatology, pulmonary medicine, endocrinology, and cardiology published between 2000 and 2012.

Main outcome measures Prevalence proportion of acronyms and composite quality score for acronyms over time.

Results 14965 publications were identified, of which 18.3\% ( $n=2737)$ contained an acronym in the title. Acronym use was more common among cardiological studies than among the other four medical specialties (40\% v8-15\% in 2012, $\mathrm{P}<0.001)$. Except for within cardiology, the prevalence of acronyms increased over time, with the average prevalence proportion among the remaining four specialties increasing from $4.0 \%$ to $12.4 \%$ from 2000 to 2012 ( $P<0.001)$. The median combined acronym quality score decreased significantly over the study period $(P<0.001)$, from a median 9.25 in 2000 to 5.50 in 2012.
\end{abstract}

Conclusion From 2000 to 2012 the prevalence of acronyms in trial
reports increased, coinciding with a substantial decrease in the technical
and aesthetic quality of the acronyms. Strict enforcement of current
guidelines on acronym construction by journal editors is necessary to
ensure the proper use of acronyms in the future.
Introduction
Acronyms-abbreviations formed from the initial components
of a phrase or word ${ }^{1}$-improve the perception of complex,
written information. ${ }^{23}$ Within the health sciences, researchers
use of acronyms holds a long tradition, with the likely intention
of branding their work into the minds of fellow researchers,
clinicians, editors, or lay people.
The use of acronyms in health sciences has been subject to
intense debate. ${ }^{5}$ Authors have advocated against such use as
they claim it has turned into MMMMM-a major malady of
modern medical miscommunication ${ }^{6}$-and asserted that positive
sounding acronyms are misused in clinical trials with negative
outcomes.
eliminating It has been suggested that editors should insist on eliminating the use of positive sounding acronyms ${ }^{9}$ or even bring a HALT (help acronyms leave (medical) trials) to the use of acronyms altogether. ${ }^{10}$ 
This heated controversy seems to be based on opinion rather than founded on rigorous scientific research. Few quantitative studies of this important topic exist, and to our knowledge studies on the technical and aesthetic quality of acronyms are virtually absent. We describe the extent and quality of acronym use within different medical specialties.

\section{Methods}

We included five major medical specialties in the analysis: cardiology, endocrinology, rheumatology, pulmonary medicine, and psychiatry. For each specialty we selected a disease that was central to the discipline and identified the most appropriate $\mathrm{MeSH}$ term for that disease. Using these MeSH terms, we searched PubMed for studies containing acronyms in their title that did not refer to a method (for example, randomised controlled trial). We restricted the search to randomised controlled trials in humans, reported in English, and published during 2000-12.

\section{Acronym identification}

In the included studies we looked for the meaning of the acronym in several sources in the order of title, abstract, full text, and trial registration (if any). $\mathrm{AP}, \mathrm{MBH}$, and $\mathrm{MRH}$ performed the initial search, further aided by CG, TBS, KSL, PMM, LHVM, and DD in identifying acronyms. In case of any uncertainty by the single reviewer, the information was double checked by both MBH and MRH.

\section{Acronym evaluation}

The evaluation consisted of both positive (BEAUTY, Boosting Elegant Acronyms Using a Tally Yardstick) and negative (CHEATING, obsCure and awkHward usE of lettArs Trying to spell somethING) criteria (box). We used a two step Delphi method to agree on these criteria. ${ }^{11}$ The final score assigned to each acronym was obtained by adding the BEAUTY and CHEATING score.

To assess the inter-rater reliability of the combined score we rescored 100 randomly selected acronyms. ${ }^{12}{ }^{13} \mathrm{We}$ also subjectively evaluated whether the acronym could be considered as "cool" (for example, had a witty cultural reference) or pretentious, or the quality of the language of the full title had suffered in a strained attempt to make the acronym fit better. We did not include these subjective measures in the overall score.

Finally, we identified a list of honourable and dishonourable mentions that for some reason did not obtain a particularly high or low score but still deserve to be highlighted.

\section{Analysis}

We reported the proportion of acronym use and the median quality score of acronyms over time. We reported the 25 highest and lowest scoring acronyms and the honourable and dishonourable mentions selected by the reviewers. One way analysis of variance was used to compare overall scores between different medical specialties. To determine if the prevalence of acronyms in cardiology was higher than that in the other specialties, we performed a $\chi^{2}$ test. The change in quality of acronyms over time was assessed using a Spearman's rank correlation. For the top and bottom 25 acronyms, we identified the impact factor of the publishing journal in the year of publication, total number of citations, and average yearly citations. ${ }^{14} \mathrm{We}$ compared the 25 highest and lowest scoring acronyms using an unpaired Student's $t$ test after log transformation.

\section{Results}

A total of 14965 publications were identified, most of which were within the disciplines of cardiology $(n=5063)$ and endocrinology $(n=4994)$. Overall, 18.3\% $(n=2737)$ of the publications contained a total of 1149 unique acronyms (table $1 \Downarrow)$. The prevalence proportion of acronyms increased over time for all specialties, except for cardiology $(\mathrm{P}<0.01$, fig $1 \Downarrow)$.

Excluding 197 acronyms where we could not identify the full meaning, 952 acronyms underwent further evaluation. The median quality score was 6.5 , with scores ranging from -18 to 22 (interquartile range 3.0-10.5). One way analysis of variance showed that the correlation between score and medical specialty was not statistically significant. Tables $2 \Downarrow$ and $3 \Downarrow$ present the 25 highest and lowest scoring acronyms. Over the study period the acronym quality score declined significantly $(\mathrm{P}<0.01$, fig $2 \Downarrow$ ). The honourable and dishonourable mentions are listed in tables $4 \Downarrow$ and $5 \Downarrow$.

The intraclass correlation coefficient of the combined score was 0.91 (95\% confidence interval 0.86 to 0.94 ), indicating almost perfect agreement.

Overall, $4.4 \%(n=42)$ of the acronyms contained poor language in an attempt to improve on the acronym, $11.5 \%(n=109)$ were designated as "cool," with cardiology and pulmonary medicine in the lead with $12.9 \%$ and $10.7 \%$, respectively, and psychiatry, rheumatology, and endocrinology following with $2.8 \%, 5.8 \%$ and $9.8 \%$, respectively. Although $12.8 \%(\mathrm{n}=122)$ of all acronyms were classified as excessively pretentious, this proportion varied between specialties: from psychiatry $(19.4 \%)$, rheumatology (15.4\%), pulmonary medicine (14.3\%), endocrinology (13.9\%), to, lastly, cardiology (11.8\%).

The top 25 acronyms were published in journals with a median impact factor of 10.2 (interquartile range 6.8-28.9), whereas the bottom 25 had a median impact factor of 6.1 (3.3-11.4). This difference failed to reach significance $(\mathrm{P}=0.05)$. The top 25 acronyms had more total citations (median $69 v 29, \mathrm{P}=0.02$ ), whereas citations per year did not differ significantly (median $14 v 7, \mathrm{P}=0.09$ ).

\section{Discussion}

This quantitative and qualitative systematic study showed an increasing use of acronyms in the manuscript titles of four major medical specialties coinciding with a noticeable decline in the quality of the acronyms over time.

Cardiologists' obsession with acronyms is well documented and has been the subject of in-depth analysis. ${ }^{68}{ }^{15-18}$ Although the " 10 commandments of acronymology" was suggested in $2003,{ }^{6}$ these were never formally adopted by any cardiological society. No biologically plausible reason explains the apparent obsession with acronyms in cardiology. It may be hypothesised that fierce academic competition spurred the origin of such use, and that new researchers have been subject to peer pressure and assigned acronyms at all cost to avoid academic marginalisation and ridicule. Another hypothesis is a reversal of the process: cardiologists may first concoct a clever acronym and then design a trial to fit that acronym.

Between the top 25 and bottom 25 acronyms, studies with good acronyms had more citations than studies with poor acronyms. For manuscript titles with good acronyms we observed a non-significant trend towards publication in journals with a 


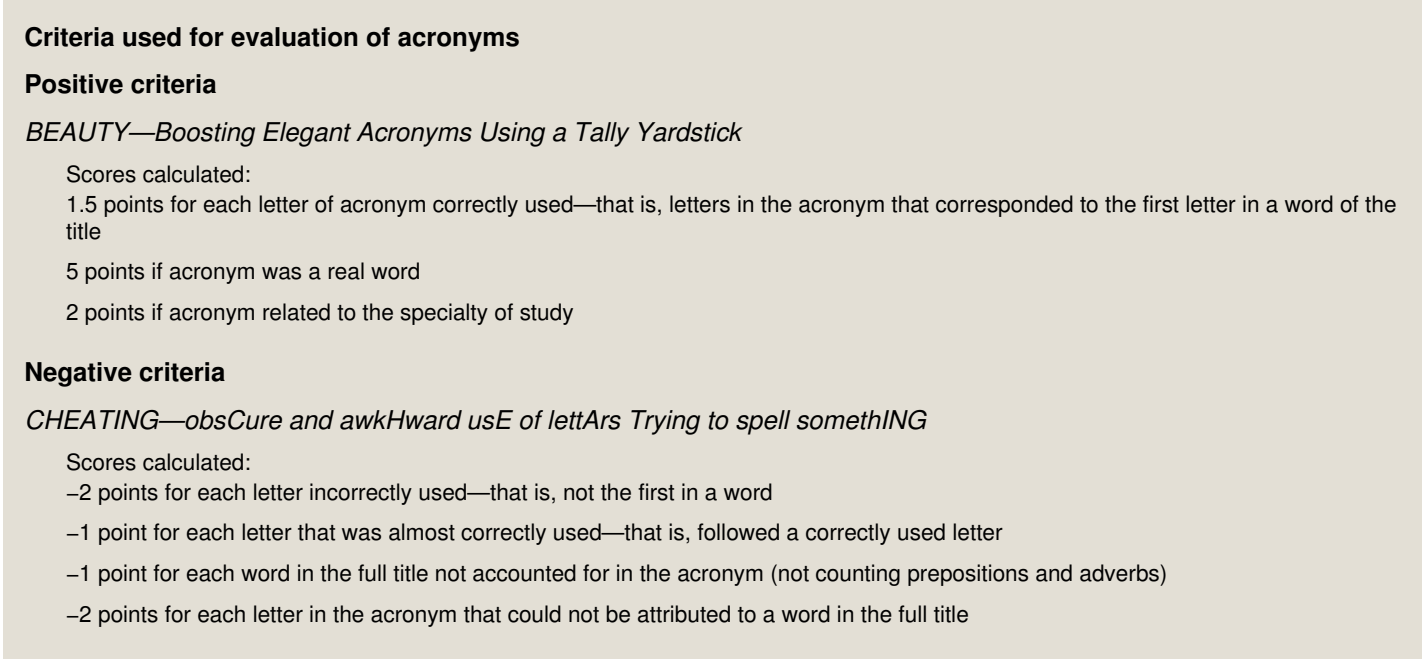

higher impact factor. Bibliometric assessment of academic production is closely associated with successful funding, ${ }^{19}{ }^{20}$ as well as personal satisfaction, pride, and peer prestige of researchers. ${ }^{21-23}$ In line with our findings, a study found that using an acronym was associated with a twofold increase in annual citation rate. ${ }^{24}$ Furthermore, the length of a manuscript's title has been identified as an independent predictor of citation rate..$^{25}$ In that study, however, the authors failed to account for acronymisation in their regression model. This possibly represents a strong confounder, and we are confident that adjusting for acronym use would eliminate the apparent signal from title length. ${ }^{25} \mathrm{~A}$ causal relation cannot be inferred from our results though, and the issue of reverse causality remains a concern. We cannot exclude that well chosen and aesthetically satisfying acronyms increase the impact factor of the journals publishing them. However, we find it reassuring that acronyms that are technically correct and aesthetically satisfying are seemingly appropriately rewarded.

\section{The Tolstoy manoeuvre}

We observed several examples of what we designate the Tolstoy manoeuvre: if the title appears to quote extensive passages from War and Peace (>1400 pages), authors can fit any desired acronym by cherry picking letters. A striking example is ADJUST (Abatacept study to Determine the effectiveness in preventing the development of rheumatoid arthritis in patients with Undifferentiated inflammatory arthritis and to evaluate Safety and Tolerability, table 3). Incidentally, this represents a failed Tolstoy manoeuvre, as the " $\mathrm{J}$ " is not accounted for.

\section{The good}

Good acronyms are thoughtful, well designed, orthographically correct, and aesthetically satisfying. Acronyms such as CHARISMA, PREDICTIVE, and CAPTIVATE (table 3) are excellent examples and all likely to serve the purpose of the acronymisation to a meaningful extent. For pure inventiveness and imagination, some very good acronyms were included on the honourable mentions list, such as HI-5, DESSERT, and RATPAC (table 4).

\section{The bad}

The RATIONAL, RECOVER, and EXAMINE (table 3) acronyms may at first glance appear quite reasonable. On further examination, however, these acronyms reveal themselves to be poorly constructed. Consider the completely wonderful RATIONAL acronym, derived from "aspiRin stAtins or boTh for the reductIon of thrOmbin geNeration in diAbetic peopLe." Orthographically, a worse acronym than this is literally impossible to construct. Although the acronym signifies that the study presents rational, clinically important data, as in "rational pharmacotherapy" or "rational allocation of resources," such connotations seem disproportionate to the findings of the study. ${ }^{26}$

\section{The ugly}

We identified several acronyms that were seemingly randomly put together at the authors' discretion and did not remotely resemble a recognisable word or phrase. Prominent examples include POLMIDES, ARMYDA-5, and METGO (table 3). The dishonourable mentions list includes abominations such as SU.FOL.OM3 and P-No SOS (table 5), leaving acronymologists around the world wondering why the authors bothered in the first place.

We conclude that the prevalence of acronyms in reports on clinical trials is increasing at the expense of their semantic and aesthetic quality. Given the academic importance of acronyms, we are surprised by the lack of effort dedicated to their construction. The growth of acronym use, especially those of poor quality, should be resisted. ${ }^{27}$ We believe that strict governance of current guidelines by journal editors will result in an aesthetic improvement and better use of acronyms.

Contributors: AP, JH, and PD were responsible for the overall planning of the study. AP and TBS performed the statistical analyses and data management. All authors made major contributions to the planning of the study, data collection, and subsequent reporting of the work. PD, $\mathrm{AP}$, and $\mathrm{JH}$ primarily drafted the manuscript. All authors revised the manuscript for important intellectual content and approved the final version. AP is the guarantor. The study design; collection, analysis, and interpretation of data; writing of the article; and decision to submit for publication were independent of any funding body. All researchers had access to all the data.

Funding: No specific funding.

Competing interests: All authors have completed the ICMJE uniform disclosure form at www.icmje.org/coi_disclosure.pdf (available on request from the corresponding author) and declare: no support from any organisation for the submitted work; no financial relationships with any organisations that might have an interest in the submitted work in the previous three years; AP, JH, KSL, MRH, and PD have participated in studies using acronyms.

Ethical approval: Not required. 


\section{What is already known on this topic}

The use of acronyms by medical researchers to brand their studies in the minds of clinicians and fellow researchers is subject to controversy

The use of acronyms may be associated with a higher annual citation rate

\section{What this study adds}

The proportion of trials within major disease entities in rheumatology, endocrinology, pulmonary medicine, and psychiatry that uses acronyms is increasing

The technical and aesthetic quality of acronyms is decreasing

Data sharing: Statistical code and datasets are available from the corresponding author at apottegaard@health.sdu.dk.

Transparency: The corresponding author (AP) affirms that the manuscript is an honest, accurate, and transparent account of the study being reported; that no important aspects of the study have been omitted; and that any discrepancies are disclosed.

Webster's dictionary. 2014. www.webster-dictionary.org/definition/acronym

2 Laszlo S, Federmeier KD. The acronym superiority effect. Psychol Bull Rev 2007;14:1158-63.

3 Playfoot D, Izura C. Imageability, age of acquisition, and frequency factors in acronym comprehension. Q J Exp Psychol 2006 2013;66:1131-45.

4 Berkwits M. Capture! Shock! Excite! Clinical trial acronyms and the 'branding' of clinical research. Ann Intern Med 2000;133:755-62.

5 Berlin L. TAC: AOITROMJA? (the acronym conundrum: advancing or impeding the readability of medical journal articles?). Radiology 2013;266:383-7.

6 Fred HL, Cheng TO. Acronymesis: the exploding misuse of acronyms. Tex Heart Inst J Tex Heart Inst St Lukes Episcop Hosp Tex Child Hosp 2003:30:255-7.

7 Orlowski JP, Christensen JA. The potentially coercive nature of some clinical research trial acronyms. Chest 2002;121:2023-8.

8 Cheng TO. What is the ZAHARA study? Acronymania is an incurable Disease Afflicting MAiNly the cardiologisTs (ADAMANT). Int J Cardiol 2009;137:289; author reply 290.

9 Isles AF, Pearn JH. Acronyms confuse everyone: combating the use of acronyms to describe paediatric research studies. J Paediatr Child Health 2014; published online 6 Jun.

10 Oransky I. HALT: Help acronyms leave (medical) trials. 2006. www.boston.com/yourlife/ health/diseases/articles/2006/08/13/halt_help_acronyms_leave_medical_trials/.

11 Dalkey N, Helmer O. An experimental application of the Delphi method to the use of experts. Manag Sci 1963:9;458-67.

12 Müller R, Büttner P. A critical discussion of intraclass correlation coefficients. Stat Med 1994:13:2465-76.

13 Uebersax J. Intraclass correlation and related methods. 2014. www.john-uebersax.com/ stat/icc.htm.

14 Thomson Reuters. Web of knowledge. 2014. www.webofknowledge.com.
15 Cheng TO. What is the THAMES study? [Letter] Eur Heart $J$ 1994:15:720.

16 Cheng TO. Use of the acronym SMART in a title is not very smart. Am J Hypertens 1997;10:141-2.

17 Cheng TO. PASTA is good, but SUSHI is better. Catheter Cardiovasc Interv Off J Soc Card Angiogr Interv 2000;49:478-9.

18 Cheng TO. What's in a name? Another unexplained acronym! Int J Cardiol 2010;144:291-2.

19 Svider PF, Mauro KM, Sanghvi S, Setzen M, Baredes S, Eloy JA. Is NIH funding predictive of greater research productivity and impact among academic otolaryngologists? Laryngoscope 2013;123:118-22.

20 Nishijima DK, Dinh T, May L, Yadav K, Gaddis GM, Cone DC. Quantifying federal funding and scholarly output related to the academic emergency medicine consensus conferences. Acad Med J Assoc Am Med Coll 2014:89:176-81.

21 Yue W, Wilson CS, Boller F. Peer assessment of journal quality in clinical neurology. $J$ Med Libr Assoc 2007;95:70-6.

22 Bhattacharjee Y. Citation impact. Saudi universities offer cash in exchange for academic prestige. Science $2011 ; 334: 1344-5$

23 Murphy EJ. Citations: the rules they didn't teach you. Lipids 2011;46:307-9.

24 Stanbrook MB, Austin PC, Redelmeier DA. Acronym-named randomized trials in medicine-the ART in medicine study. N Engl J Med 2006;355:101-2.

25 Falagas ME, Zarkali A, Karageorgopoulos DE, Bardakas V, Mavros MN. The impact of article length on the number of future citations: a bibliometric analysis of general medicine journals. PloS One 2013;8:e49476.

26 Macchia A, Laffaye N, Comignani PD, Comejo Pucci E, Igarzabal C, Scazziota AS, et al. Statins but not aspirin reduce thrombotic risk assessed by thrombin generation in diabetic patients without cardiovascular events: the RATIONAL trial. PloS One 2012;7:e32894.

27 Cheng TO. Acronymophilia. BMJ 1994;309:683-4.

\section{Accepted: 7 November 2014}

\section{Cite this as: BMJ 2014;349:g7092}

This is an Open Access article distributed in accordance with the Creative Commons Attribution Non Commercial (CC BY-NC 4.0) license, which permits others to distribute, remix, adapt, build upon this work non-commercially, and license their derivative works on different terms, provided the original work is properly cited and the use is non-commercial. See: http://creativecommons.org/licenses/by-nc/4.0/. 


\section{Tables}

Table 1| Basic search algorithm and results

\begin{tabular}{llccc} 
Specialty & \multicolumn{1}{c}{ MeSH term } & No of studies & No (\%) with acronym in title & Total No of acronyms \\
Cardiology & Myocardial infarction & 5063 & $1912(37.8)$ & 804 \\
\hline Endocrinology & Diabetes mellitus, type 2 & 4994 & $618(12.4)$ & 299 \\
\hline Rheumatology & Arthritis, rheumatoid & 1404 & $114(8.1)$ & 69 \\
\hline Pulmonary medicine & Pulmonary disease, chronic obstructive & 1691 & $86(5.1)$ & 50 \\
\hline Psychiatry & Depressive disorder, major & 2284 & $150(6.6)$ & 49 \\
\hline Total ${ }^{*}$ & & 14965 & $2737(18.3)$ & 1149 \\
\hline
\end{tabular}




\begin{tabular}{|c|c|c|c|c|c|c|c|}
\hline Total score & Acronym & Full name ${ }^{\star}$ & Specialty & $\begin{array}{l}\text { Publication } \\
\text { year }\end{array}$ & Impact factor & $\begin{array}{c}\text { No of } \\
\text { citationst }\end{array}$ & $\begin{array}{c}\text { Citations } \\
\text { /yeart }\end{array}$ \\
\hline 22.0 & PREDICTIVE & $\begin{array}{l}\text { Predictable Results and Experience in Diabetes through } \\
\text { Intensification and Control to Target: An International } \\
\text { Variability Evaluation }\end{array}$ & EN & 2008 & 31.7 & 28 & 4.7 \\
\hline 20.5 & PERISCOPE & $\begin{array}{l}\text { Pioglitazone Effect on Regression of Intravascular } \\
\text { Sonographic Coronary Obstruction Prospective Evaluation }\end{array}$ & EN & 2008 & 31.7 & 375 & 53.6 \\
\hline 19.5 & IMMEDIATE & $\begin{array}{l}\text { Immediate Myocardial Metabolic Enhancement During Initial } \\
\text { Assessment and Treatment in Emergency care }\end{array}$ & $\mathrm{CA}$ & 2012 & 30.0 & 44 & 14.7 \\
\hline 18.5 & PRECISION & $\begin{array}{l}\text { Prospective Randomized Evaluation of Celecoxib Integrated } \\
\text { Safety versus Ibuprofen Or Naproxen }\end{array}$ & $\mathrm{CA}$ & 2009 & 4.4 & 36 & 6.0 \\
\hline 18.0 & BARRICADE & $\begin{array}{l}\text { Barrier approach to restenosis: restrict intima to curtail } \\
\text { adverse events }\end{array}$ & $\mathrm{CA}$ & 2011 & 6.8 & 10 & 2.5 \\
\hline 17.5 & BRONCUS & Bronchitis Randomized on NAC Cost-Utility Study & PU & 2005 & 23.4 & 274 & 27.4 \\
\hline 17.5 & CAPTIVATE & $\begin{array}{l}\text { Carotid Atherosclerosis Progression Trial Investigating } \\
\text { Vascular ACAT Inhibition Treatment Effects }\end{array}$ & $\mathrm{CA}$ & 2009 & 28.9 & 60 & 10.0 \\
\hline 17.5 & PRISM-PLUS & $\begin{array}{l}\text { Platelet Receptor Inhibition in Ischemic Syndrome } \\
\text { Management in Patients Limited by Unstable Signs and } \\
\text { Symptoms }\end{array}$ & $\mathrm{CA}$ & 2000 & 10.9 & 46 & 3.1 \\
\hline 17.0 & DECREASE & $\begin{array}{l}\text { Dutch Echocardiographic Cardiac Risk Evaluation Applying } \\
\text { Stress Echocardiography }\end{array}$ & $\mathrm{CA}$ & 1999 & 28.9 & 816 & 51.0 \\
\hline 17.0 & CHARISMA & $\begin{array}{l}\text { Clopidogrel for High Atherothrombotic Risk and Ischemic } \\
\text { Stabilization, Management, and Avoidance }\end{array}$ & $\mathrm{CA}$ & 2004 & 3.7 & 126 & 11.5 \\
\hline 17.0 & CADILLAC & $\begin{array}{l}\text { Controlled Abciximab and Device Investigation to Lower } \\
\text { Late Angioplasty Complications }\end{array}$ & $\mathrm{CA}$ & 2002 & 29.1 & 801 & 61.6 \\
\hline 17.0 & INTERCEPT & $\begin{array}{l}\text { Incomplete Infarction Trial of European Research } \\
\text { Collaborators Evaluating Prognosis post-Thrombolysis }\end{array}$ & $\mathrm{CA}$ & 2000 & 10.2 & 49 & 3.3 \\
\hline 17.0 & MR-IMPACT & $\begin{array}{l}\text { Magnetic Resonance Imaging for Myocardial Perfusion } \\
\text { Assessment in Coronary Artery Disease Trial }\end{array}$ & $\mathrm{CA}$ & 2008 & 8.9 & 216 & 30.9 \\
\hline 16.0 & PLASMA & $\begin{array}{l}\text { Phospholipase Levels and Serological Markers of } \\
\text { Atherosclerosis }\end{array}$ & PU & 2009 & 30.8 & 72 & 12.0 \\
\hline 16.0 & InTIME & $\begin{array}{l}\text { Intravenous NPA for the treatment of infarcting myocardium } \\
\text { early }\end{array}$ & $\mathrm{CA}$ & 2000 & 3.8 & 108 & 7.2 \\
\hline 16.0 & IMPACT & $\begin{array}{l}\text { Improving Mood with Psychoanalytic and Cognitive } \\
\text { Therapies }\end{array}$ & PS & 2011 & 2.1 & 9 & 2.3 \\
\hline 16.0 & MICRO-HOPE & $\begin{array}{l}\text { Microalbuminuria Cardiovascular Renal Outcomes - Heart } \\
\text { Outcomes Prevention Evaluation }\end{array}$ & $\mathrm{CA}$ & 2000 & 10.2 & - & - \\
\hline 16.0 & BRIDGE & $\begin{array}{l}\text { Blacks Receiving Interventions for Depression and Gaining } \\
\text { Empowerment }\end{array}$ & PS & 2013 & 2.5 & 2 & 1.0 \\
\hline 16.0 & APHRODITE & $\begin{array}{l}\text { Active Prevention in High-Risk Individuals of Diabetes Type } \\
2 \text { in and Around Eindhoven }\end{array}$ & EN & 2011 & 8.1 & 13 & 3.3 \\
\hline 16.0 & CRUISE & Can Routine Ultrasound Influence Stent Expansion & $\mathrm{CA}$ & 2000 & 10.9 & 217 & 14.5 \\
\hline 15.5 & SENIORS & $\begin{array}{l}\text { Study of the Effects of Nebivolol Intervention on Outcomes } \\
\text { and Rehospitalisation in Seniors with Heart Failure }\end{array}$ & $\mathrm{CA}$ & 2005 & 7.3 & 548 & 54.8 \\
\hline 15.5 & CAPTORS & $\begin{array}{l}\text { Collaborative Angiographic Patency Trial Of Recombinant } \\
\text { Staphylokinase }\end{array}$ & $\mathrm{CA}$ & 2000 & 2.4 & 19 & 1.3 \\
\hline 15.5 & DESMOND & $\begin{array}{l}\text { Diabetes Education and Self Management for Ongoing and } \\
\text { Newly Diagnosed type } 2 \text { Diabetes }\end{array}$ & EN & 2008 & 12.8 & 158 & 22.6 \\
\hline 15.5 & ESSENCE & $\begin{array}{l}\text { Efficacy and Safety of Subcutaneous Enoxaparin in } \\
\text { Non-Q-Wave Coronary Events }\end{array}$ & $\mathrm{CA}$ & 1997 & 27.8 & 1089 & 60.5 \\
\hline 15.5 & COMPETE & $\begin{array}{l}\text { Computerization of Medical Practices for the Enhancement } \\
\text { of Therapeutic Effectiveness }\end{array}$ & EN & 2009 & 7.7 & 66 & 11.0 \\
\hline
\end{tabular}

$\mathrm{CA}=$ cardiology; $\mathrm{EN}=$ endocrinology; $\mathrm{PU}=$ pulmonary medicine; $\mathrm{PS}=$ psychiatry.

${ }^{*}$ Capitalisation is identical to that done by authors of single study.

†Source: Web of Knowledge. ${ }^{14}$ 


\begin{tabular}{|c|c|c|c|c|c|c|c|}
\hline Total score & Acronym & Full name ${ }^{*}$ & Specialty & $\begin{array}{l}\text { Publication } \\
\text { year }\end{array}$ & $\begin{array}{l}\text { Impact } \\
\text { factor }\end{array}$ & $\begin{array}{l}\text { No of } \\
\text { citations }\end{array}$ & Citations/year $†$ \\
\hline-18.0 & METGO & $\begin{array}{l}\text { A 48-week, randomized, double-blind, double-observer, } \\
\text { placebo-controlled multicenter trial of combination } \\
\text { METhotrexate and intramuscular GOld therapy in } \\
\text { rheumatoid arthritis: results of the METGO study }\end{array}$ & $\mathrm{RH}$ & 2005 & 7.4 & 57 & 5.7 \\
\hline-18.0 & PERFORM & $\begin{array}{l}\text { Prevention of cerebrovascular and cardiovascular Events } \\
\text { of ischaemic origin with teRutroban in patients with a history } \\
\text { of ischaemic strOke or tRansient ischaeMic attack }\end{array}$ & $\mathrm{CA}$ & 2011 & 38.3 & 68 & 17.0 \\
\hline-16.5 & TYPHOON & $\begin{array}{l}\text { Trial to assess the use of the CYPHer sirolimus-eluting } \\
\text { coronary stent in acute myocardial infarction treated with } \\
\text { BallOON angioplasty }\end{array}$ & $\mathrm{CA}$ & 2011 & 6.8 & 50 & 12.5 \\
\hline-14.5 & T-VENTURE & $\begin{array}{l}\text { inhibitory effect of valsartan against progression of lefT } \\
\text { VENTricUlaR dysfunction aftEr myocardial infarction }\end{array}$ & $\mathrm{CA}$ & 2009 & 2.7 & 11 & 1.8 \\
\hline-13.5 & POLMIDES & $\begin{array}{l}\text { Prospective randomised pilOt study evaLuating the safety } \\
\text { and efficacy of hybrid revascularisation in Multl-vessel } \\
\text { coronary artery DisEaSe }\end{array}$ & $\mathrm{CA}$ & 2011 & 0.5 & 2 & 0.5 \\
\hline-13.0 & BEAUTIFUL & $\begin{array}{l}\text { morBidity-mortality EvAIUaTion of the If inhibitor ivabradine } \\
\text { in patients with coronary disease and left ventricULar } \\
\text { dysfunction }\end{array}$ & $\mathrm{CA}$ & 2008 & 28.4 & 355 & 50.7 \\
\hline-12.0 & CILON-T & $\begin{array}{l}\text { Influence of CILostazol-based triple antiplatelet therapy ON } \\
\text { Ischemic Complication after drug-eluting stenT implantation }\end{array}$ & $\mathrm{CA}$ & 2011 & 14.2 & 83 & 20.8 \\
\hline-12.0 & AMEthyst & $\begin{array}{l}\text { Assessment of the Medtronic AVE Interceptor Saphenous } \\
\text { Vein Graft Filter System }\end{array}$ & $\mathrm{CA}$ & 2008 & 7.4 & 15 & 2.1 \\
\hline-11.0 & EUCATAX & $\begin{array}{l}\text { Efficacy and safety of a double-coated paclitaxel-eluting } \\
\text { coronary stent }\end{array}$ & $\mathrm{CA}$ & 2011 & 2.3 & 3 & 0.8 \\
\hline-11.0 & RATIONAL & $\begin{array}{l}\text { aspiRin stAtins or boTh for the reductlon of thrOmbin } \\
\text { geNeration in diAbetic peopLe }\end{array}$ & EN & 2012 & 3.7 & 6 & 2.0 \\
\hline-10.5 & $\begin{array}{l}\text { ARMYDA-5 } \\
\text { PRELOAD }\end{array}$ & $\begin{array}{l}\text { Antiplatelet therapy for Reduction of MYocardial Damage } \\
\text { during Angioplasty }\end{array}$ & $\mathrm{CA}$ & 2010 & 14.3 & 26 & 5.2 \\
\hline-10.5 & METOCARD-CNIC & $\begin{array}{l}\text { Effect of METOprolol in CARDioproteCtioN during an acute } \\
\text { myocardial InfarCtion }\end{array}$ & $\mathrm{CA}$ & 2012 & 4.5 & 7 & 2.3 \\
\hline-10.5 & SIRTAX & $\begin{array}{l}\text { SIRolimus-eluting stent compared with pacliTAXel-eluting } \\
\text { stent for coronary revascularization }\end{array}$ & $\mathrm{CA}$ & 2005 & 44.0 & 373 & 37.3 \\
\hline-9.0 & FABOLUS PRO & $\begin{array}{l}\text { Facilitation through Aggrastat By drOpping or shortening } \\
\text { Infusion Line in patients with ST-segment elevation } \\
\text { myocardial infarction compared to or on top of PRasugrel } \\
\text { given at loading dOse }\end{array}$ & $\mathrm{CA}$ & 2012 & 6.6 & 33 & 11.0 \\
\hline-8.5 & REGENT & $\begin{array}{l}\text { Myocardial Regeneration by Intracoronary Infusion of } \\
\text { Selected Population of Stem Cells in Acute Myocardial } \\
\text { Infarction }\end{array}$ & $\mathrm{CA}$ & 2009 & 9.8 & 196 & 32.7 \\
\hline-8.5 & ORLICARDIA & $\begin{array}{l}\text { ORLIstat and CArdiovascular risk profile in patients with } \\
\text { metabolic syndrome and type } 2 \text { DIAbetes }\end{array}$ & EN & 2004 & 2.9 & 29 & 2.6 \\
\hline-8.0 & SCANDSTENT & Stenting Coronary Arteries in Non-Stress/Benestent Disease & $\mathrm{CA}$ & 2006 & 11.4 & 69 & 7.7 \\
\hline-8.0 & RECOVER & $\begin{array}{l}\text { REstoration of COronary flow in patients with no-reflow } \\
\text { after primary coronary interVEntion of acute myocaRdial } \\
\text { infarction }\end{array}$ & $\mathrm{CA}$ & 2012 & 4.5 & 4 & 1.3 \\
\hline-8.0 & Carbostent & $\begin{array}{l}\text { Carbofilm-coated stent versus a pure high-grade stainless } \\
\text { steel stent }\end{array}$ & $\mathrm{CA}$ & 2004 & 3.1 & 21 & 1.9 \\
\hline-7.0 & VINO & $\begin{array}{l}\text { Value of First Day Angiography/Angioplasty In Evolving } \\
\text { Non-ST Segment Elevation Myocardial Infarction: An Open } \\
\text { Multicenter Randomized Trial }\end{array}$ & $\mathrm{CA}$ & 2002 & 6.1 & 95 & 7.3 \\
\hline-7.0 & METIS & $\begin{array}{l}\text { The effects of METhotrexate therapy on the physical } \\
\text { capacity of patients with ISchemic heart failure }\end{array}$ & $\mathrm{CA}$ & 2009 & 3.3 & 4 & 0.7 \\
\hline-7.0 & STLLR & $\begin{array}{l}\text { Stent deployment Techniques on cLinical outcomes of } \\
\text { patients treated with the cypheRstent }\end{array}$ & $\mathrm{CA}$ & 2008 & 3.9 & 59 & 8.4 \\
\hline-6.5 & COMFORTABLE & $\begin{array}{l}\text { Comparison of Biolimus Eluted From an Erodible Stent } \\
\text { Coating With Bare Metal Stents }\end{array}$ & $\mathrm{CA}$ & 2012 & 3.3 & 6 & 2.0 \\
\hline-6.5 & EXPIRA & $\begin{array}{l}\text { Impact of Thrombectomy with EXPort Catheter in } \\
\text { Infarct-Related Artery during Primary Percutaneous } \\
\text { Coronary Intervention }\end{array}$ & $\mathrm{CA}$ & 2009 & 12.5 & 143 & 23.8 \\
\hline
\end{tabular}


Table 3 (continued)

\begin{tabular}{|c|c|c|c|c|c|c|c|}
\hline Total score & Acronym & Full name* & Specialty & $\begin{array}{c}\text { Publication } \\
\text { year }\end{array}$ & $\begin{array}{l}\text { Impact } \\
\text { factor }\end{array}$ & $\begin{array}{c}\text { No of } \\
\text { citationst }\end{array}$ & Citations/year† \\
\hline-6.5 & EXAMINE & $\begin{array}{l}\text { EXamination of cArdiovascular outcoMes with alogliptIN } \\
\text { versus standard of carE in patients with type } 2 \text { diabetes } \\
\text { mellitus and acute coronary syndrome }\end{array}$ & $\mathrm{CA}$ & 2011 & 4.7 & 26 & 6.5 \\
\hline
\end{tabular}

$\mathrm{CA}=$ cardiology; $\mathrm{EN}=$ endocrinology; $\mathrm{RH}=$ rheumatology.

${ }^{*}$ Capitalisation is identical to that done by authors of single study.

†Source: Web of Knowledge. ${ }^{14}$ 
Table 4| Honourable mentions

\begin{tabular}{|c|c|c|}
\hline Acronym & Full name* & Specialty \\
\hline CHAMPION & Cangrelor versus standard tHerapy to Achieve optimal Management of Platelet InhibitiON & $\mathrm{CA}$ \\
\hline ONTARGET & Ongoing Telmisartan Alone and in Combination With Ramipril Global End Point Trial & $\mathrm{CA}$ \\
\hline EXAMINATION & Clinical Evaluation of the Xience-V stent in Acute Myocardial INfArcTION & $\mathrm{CA}$ \\
\hline RATPAC & Randomised Assessment of Treatment using Panel Assay of Cardiac markers & $\mathrm{CA}$ \\
\hline ALBATROSS & $\begin{array}{l}\text { Aldosterone Lethal effects Blocked in Acute myocardial infarction Treated with or without Reperfusion to improve } \\
\text { Outcome and Survival at Six months follow-up }\end{array}$ & CA \\
\hline ENIGMA & Evaluation of Nitrous oxide In the Gas Mixture for Anesthesia & $\mathrm{CA}$ \\
\hline PROTECT & Patient Related OuTcomes with Endeavor versus Cypher stenting Trial & $\mathrm{CA}$ \\
\hline A to $Z$ & Aggrastat to Zocor & $\mathrm{CA}$ \\
\hline DOCTORS & Debulking Of CTO with Rotational or directional atherectomy before Stenting & $\mathrm{CA}$ \\
\hline DISPERSE & $\begin{array}{l}\text { Dose conflrmation Study assessing anti-Platelet Effects of AZD } 6140 \text { vs. clopidogRel in non-ST-segment Elevation } \\
\text { myocardial infarction }\end{array}$ & $\mathrm{CA}$ \\
\hline ADMIRAL & $\begin{array}{l}\text { Abciximab Before Direct Angioplasty and Stenting in Myocardial Infarction Regarding Acute and Long-term } \\
\text { Follow-up }\end{array}$ & $\mathrm{CA}$ \\
\hline $4 \mathrm{D}$ & Die Deutsche Diabetes Dialyse Studie & $\mathrm{CA}$ \\
\hline VESPA & Verapamil Slow-Release for Prevention of Cardiovascular Events After Angioplasty & $\mathrm{CA}$ \\
\hline ALIVE & Azimilide Postinfarct Survival Evaluation & $\mathrm{CA}$ \\
\hline LIFE & Losartan Intervention For Endpoint reduction in hypertension & $\mathrm{CA}$ \\
\hline OPERA & Omapatrilat in Persons with Enhanced Risk of Atherosclerotic events & $\mathrm{CA}$ \\
\hline HERO & Hirulog Early Reperfusion Occlusion & $\mathrm{CA}$ \\
\hline MANTRA & Monitoring and Actualization of Noetic Training & $\mathrm{CA}$ \\
\hline $\mathrm{HI}-5$ & Hyperglycemia: Intensive Insulin Infusion in Infarction & $\mathrm{CA}$ \\
\hline CHEER & Chest pain evaluation in the emergency room & $\mathrm{CA}$ \\
\hline ILLUMINATE & Investigation of Lipid Level Management to Understand its Impact in Atherosclerotic Events & EN \\
\hline SERENADE & Study Evaluating Rimonabant Efficacy in Drug-Naive Diabetic Patients & EN \\
\hline CaRESS & Cardiovascular risk education and social support & EN \\
\hline DESSERT & Diabetes Drug Eluting Sirolimus Stent Experience in Restenosis Trial & EN \\
\hline SLIM & Study on Lifestyle intervention and Impaired glucose tolerance Maastricht & EN \\
\hline PLUTO & PLavix Use for Treatment Of Diabetes & EN \\
\hline $\mathrm{T}-4$ & Treating to Twin Targets & RA \\
\hline
\end{tabular}

$\mathrm{CA}=$ cardiology; $\mathrm{EN}=$ endocrinology.

${ }^{*}$ Capitalisation of letters is identical to that done by authors of single study. 


\section{Table 5| Dishonourable mentions}

\begin{tabular}{lll} 
Acronym & Full name* & LoSmapimod treatment on inflammation and InfarCtSizE \\
\hline SOLSTICE & Post-Myocardial Infarction Free Rx Event and Economic Evaluation & Specialty \\
\hline SU.FOL.OM3 & SUpplementation with FOLate, vitamins B-6 and B-12 and/or OMega-3 fatty acids & CA \\
\hline PRODIGY & PROlonging Dual-antiplatelet treatment after Grading stent-induced Intimal hyperplasia study \\
\hline TAXUS & Treatment of De Novo Coronary Disease Using a Single Paclitaxel-Eluting Stent \\
\hline ANTIBIO & Antibiotic Therapy in Acute Myocardial Infarction & CA \\
\hline STRATEGY & Single High-Dose Bolus Tirofiban and Sirolimus Eluting Stent Versus Abciximab and Bare Metal Stent In CA & CA \\
\hline P-No SOS & Acute Myocardial Infarction & CA \\
\hline VICTORY & Primary angioplasty in acute myocardial infarction at hospitals with no surgery on-site \\
\hline CAPPP & Veln-Coronary aTherOsclerosis and Rosiglitazone after bypass surgerY & CA \\
\hline MAXIMA & Captopril Prevention Project & EN \\
\hline ADJUST & Maintenance of Haemoglobin Excels IV Administration of C.E.R.A. \\
\hline
\end{tabular}

$\mathrm{CA}=$ cardiology; $\mathrm{EN}=$ =ndocrinology; $\mathrm{RH}=$ rheumatology; $\mathrm{PU}=$ pulmonary medicine.

${ }^{*}$ Capitalisation of letters is identical to that done by authors of single study. 


\section{Figures}

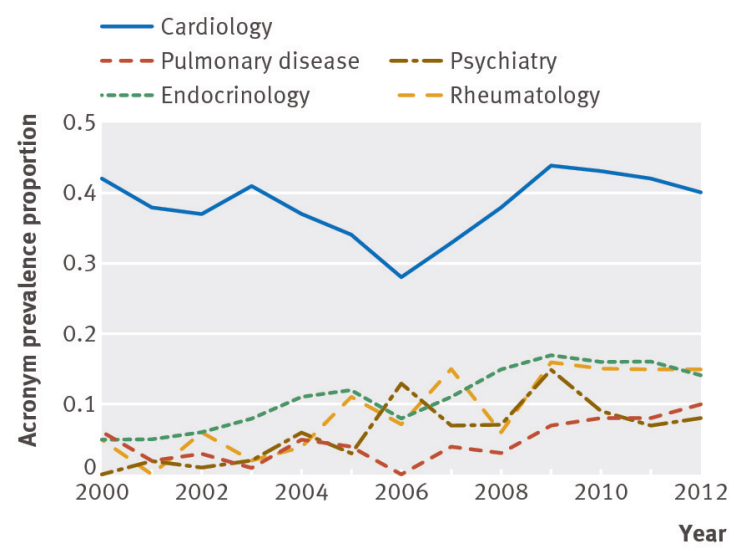

Fig 1 Prevalence proportion of acronyms over time

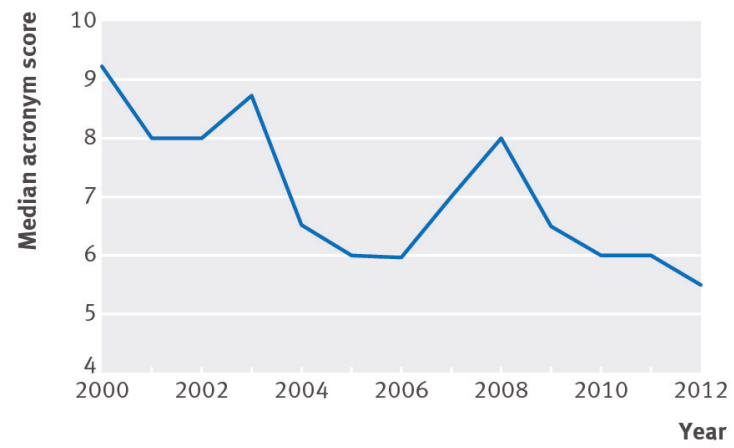

Fig 2 Median quality score for acronyms by year 